\title{
China's Policy in the East China Sea
}

The Role of Crisis Management Mechanism Negotiations with Japan

(2008-2015)

\section{Mathieu Duchâtel}

\section{(2) OpenEdition}

\section{Journals}

Electronic version

URL: http://journals.openedition.org/chinaperspectives/7021

DOI: 10.4000/chinaperspectives.7021

ISSN: 1996-4617

Publisher

Centre d'étude français sur la Chine contemporaine

\section{Printed version}

Date of publication: 1 September 2016

Number of pages: 13-21

ISSN: 2070-3449

\section{Electronic reference}

Mathieu Duchâtel, «China's Policy in the East China Sea », China Perspectives [Online], 2016/3 | 2016, Online since 01 September 2016, connection on 28 October 2019. URL : http://

journals.openedition.org/chinaperspectives/7021 ; DOI : 10.4000/chinaperspectives.7021 


\title{
China's Policy in the East China Sea
}

\section{The Role of Crisis Management Mechanism Negotiations with Japan (2008-2015)}

\author{
MATHIEU DUCHÂTEL
}

\begin{abstract}
This paper looks back at China's policy towards the establishment of a crisis management mechanism with Japan in the East China Sea from the beginning of the negotiations in 2008 to the deadlock reached at the end of 2015. During this period of seven years, China moved from being a reluctant negotiator to interrupting the negotiations and finally accepting their resumption, but only after setting such a high bar in terms of relative sovereignty gains that the talks unravelled. The paper argues that the socialisation of China to confidence-building norms in the security sphere - norms that the strategic community of the PRC traditionally rejects is making very slow progress despite the rising risk of incidents in maritime East Asia. It concludes that Chinese foreign policy uses crisis management negotiations to secure a variety of foreign policy goals linked to sovereignty and balance of power rather than a tool purely dedicated to building security and stability by freezing an existing status quo.
\end{abstract}

KEYWORDS: East China Sea, Diaoyu, Senkaku, crisis management, maritime security, confidence-building measures.

S overeignty over the Senkaku/Diaoyu Islands and the establishment of a maritime boundary with Japan in the East China Sea are two of China's remaining territorial disputes, and a foreign and national security policy priority in Beijing. The disputes have been a source of instability in China-Japan relations, with risks of military conflict arising from their overall strategic rivalry in East Asia but also from more specific military activities in the disputed areas, which in a worst case scenario could lead to unplanned collisions. This second type of risk has considerably increased in recent years as a result of China's decision to establish a more regular presence in the areas claimed by Japan, especially around the Senkaku/Diaoyu Islands, which Japan controls administratively - and for which the government of Japan does not recognise the existence of a sovereignty dispute. (1)

The history of China's policy on territorial disputes shows a willingness to compromise to reach final border settlements under certain circumstances. Taylor Fravel has demonstrated that counterintuitively, domestic insecurity was a factor of compromise in negotiations over land boundaries, while a decline of bargaining power was a factor in military escalation. (2) In maritime disputes, Fravel showed that China constantly pursued delay, with two decisions to use force in the South China Sea - against Vietnam in the Paracels (1974) and the Spratlys (1988). (3) Delay is precisely what Deng Xiaoping advised for the East China Sea and the Senkaku/Diaoyu Islands when he famously said in 1978 that the two sides "should set the issue aside for a while" because it was not "an urgent issue" and one for which "the next generation will have more wisdom." (4) In recent years, however, tensions over the Senkaku/Diaoyu Islands resulted in the appearance of crisis management negotiations on the agenda of ChinaJapan relations, while the negotiation of a settlement of the sovereignty dispute appeared to be completely unrealistic.

While China has a long record of negotiating borders, it has no record of concluding crisis management arrangements to diminish the risk of unintended crises linked to maritime disputes. The 2002 Declaration on the Conduct of Parties in the South China Sea signed with ASEAN countries is non-binding, and although it prevented the occupation of new features by claimants in the South China Sea, it failed to prevent the current cycle of tensions between China, Vietnam, and the Philippines that has included dangerous standoffs at sea. The Taiwan Strait and cross-strait relations offer no example of a crisis management mechanism to decrease the risk of incidents during periods of political tension.

Is there a preference in Chinese foreign policy for avoiding agreements that reduce military security risks with states with which it has active maritime territorial disputes? Alastair lain Johnston has analysed the development by People's Liberation Army (PLA) experts of a body of literature on crisis management, reflecting to some degree the theoretical influence of American Cold War concepts and more contemporary efforts by US thinktanks to promote the idea with counterparts in Beijing. He concludes that despite a clear increase in the attention the topic receives, a number of Chinese characteristics limit the impact of the crisis management approach on policy-making: specific PLA operational concepts, a "vision of Chinese exceptionalism," and the lack of strong crisis management institutions and mechanisms. ${ }^{(5)}$ A major obstacle to the conclusion of confidence-building agreements is to be found in China's negotiating tactics, and especially the fact that China consistently requests an endorsement of general principles as a precondition to starting technical talks when there are political stakes, which is clearly very much the case in territorial disputes. ${ }^{(6)}$ In the area of

1. According to the Ministry of Foreign Affairs of Japan (MOFA), "There is no doubt that the Senkaku Islands are clearly an inherent part of the territory of Japan, in light of historical facts and based upon international law. Indeed, the Senkaku Islands are under the valid control of Japan. There exists no issue of territorial sovereignty to be resolved concerning the Senkaku Islands." Source: website of Japanese MOFA, "Senkaku Islands," www.mofa.go.jp/region/asia-paci/senkaku (accessed on 11 March 2016).

2. Taylor Fravel, Strong Borders, Secure Nation, Cooperation and Conflict in China's Territorial Disputes, Princeton, NJ, Princeton University Press, 2008.

3. Ibid., pp. 266-269

4. As quoted by the Ministry of Foreign Affairs of the PRC on its page "Set Aside Dispute and Pursue Joint Development," www.fmprc.gov.cn/mfa_eng/ziliao_665539/3602_665543/3604_665547/ t18023.shtml (accessed on 18 July 2016).

5. Alastair lain Johnston, "The Evolution of Interstate Security Crisis-Management Theory and Practice in China," Naval War College Review, Vol. 69, No.1, winter 2016, pp. 28-71.

6. Richard H. Solomon, "Chinese Political Negotiating Behavior, 1967-1984," RAND monograph report, 1995. 
Table 1 - Japan-China crisis management mechanisms

\begin{tabular}{|c|c|c|c|}
\hline Name & $\begin{array}{c}\text { Date of channel } \\
\text { established }\end{array}$ & Government agencies & Ministries of Defence \\
\hline $\begin{array}{c}\text { Maritime and Aerial } \\
\text { Communication Mechanism }\end{array}$ & 2008 & $\begin{array}{c}\text { Prevent unintended collisions } \\
\text { between military forces }\end{array}$ \\
\hline $\begin{array}{c}\text { High-level Consultations } \\
\text { on Maritime Affairs }\end{array}$ & 2012 & $\begin{array}{c}\text { Ministries of Foreign Affairs lead delegations } \\
\text { representing government agencies involved } \\
\text { in maritime policy }\end{array}$ & $\begin{array}{c}\text { Build political confidence } \\
\text { on maritime issues }\end{array}$ \\
\hline $\begin{array}{c}\text { Maritime Search \& } \\
\text { Rescue Agreement }\end{array}$ & $\begin{array}{c}\text { 1977, principled } \\
\text { agreement in 2012 }\end{array}$ & $\begin{array}{c}\text { Ministries of Foreign Affairs, Japan Coast Guard } \\
\text { and China Maritime Safety Administration }\end{array}$ & Search and rescue joint operations \\
\hline
\end{tabular}

Source: James Przystup, John Bradford, and James Manicom, "Japan-China Maritime Confidence Building and Communications Mechanisms," Pacnet Newsletter, No. 67, 20 August 2013, https://www.csis.org/analysis/pacnet-67-japan-china-maritime-confidence-building-and-communications-mechanisms (accessed on 4 August 2016).

crisis management, which essentially in its restrictive acceptation in this article addresses behavioural and communication aspects of military forces in disputed territories (and the potentially positive political spill-over in terms of strategic trust), political preconditions are problematic because they tend to relate to sovereignty, which is precisely the area that crisis management needs to circumvent to be successful.

This paper offers a case study to contribute to the understanding of the foreign policy goals China attaches to crisis management: the negotiations over a Maritime and Aerial Communication Mechanism (MACM) with Japan in the East China Sea from the beginning of the negotiations in 2008 to the deadlock reached at the end of 2015. The MACM was conceived to facilitate communication between the Chinese and the Japanese military forces in order to prevent unintended collisions during times of close encounters. In essence, it covers only military security risks. During the seven-year period analysed in this paper, China has moved from being a reluctant negotiator to interrupting the negotiations and finally accepting their resumption, but only after setting such a high bar in terms of relative sovereignty gains that the talks unravelled. The paper argues that the socialisation of China to confidence-building norms in the security sphere - norms that the PRC's strategic community traditionally rejects - is making very slow progress despite the increasing risk of incidents in maritime East Asia. It concludes that Chinese foreign policy uses crisis management negotiations to secure a variety of foreign policy goals linked to sovereignty and balance of power rather than as a tool purely dedicated to diminishing the risk of military clashes by freezing a status quo. This suggests that Chinese foreign policy in the East China Sea does not aim at building a stable status quo but is still driven by a quest for political and territorial gain and thus is willing to accept a certain degree of risk. At the same time, the analysis shows that while the Chinese strategic community is not fully convinced of the usefulness of "crisis management" to reduce the risk of military incidents, support for the idea is making relative progress.

\section{An overview of China-Japan crisis management negotiations in the East China Sea}

In early October 2015, the Japanese press reported that negotiations with China to build a MACM in the East China Sea had reached a deadlock. ${ }^{(7)}$
PLA Daily simply reported that "the scheme was rejected by China." (8) The reason invoked by the Japanese side was that China "objected to a Japanese proposal that the mechanism would not apply to each countries' territorial waters and airspace." For Japan, extending the mechanism to territorial waters and airspace would be tantamount to acknowledging China's challenge to Japan's sovereignty over the disputed Senkaku/Diaoyu Islands. According to Tetsuo Kotani, an expert affiliated with the Japanese Ministry of Foreign Affairs, "If the mechanism is applied to territorial waters, China would misunderstand they can intrude as long as they communicate." (9) On the Chinese side, a military analyst involved in the negotiations argued that the Japanese side proposed that the exclusion of a 12 nautical miles $(\mathrm{nm})$ zone around the disputed islands be specifically endorsed in the final document, which "is unacceptable and unhelpful as no crisis management arrangement excludes the geographic area under most intense dispute." (10) Despite the two sides' stated willingness to decrease the risk of unintended collisions between their military and law-enforcement vessels and their fishing boats, the entire negotiation process unravelled as a result of a profound disagreement regarding sovereignty and effective administration over the disputed waters.

The MACM is one of three tracks of crisis management consultations between China and Japan, and the only one at the military-to-military level (see Table 1). In the context of their tense relationship in the East China Sea, China and Japan initiated crisis management negotiations in 2007, with the goal of improving communication at the political and militaryto-military levels and for confidence building. The two driving forces were the first Abe administration and Chinese Prime Minister Wen Jiabao, who provided the political impetus during their 2007 summit meeting. Their immediate concern was to prevent unintended incidents at sea from escalating into a full-blown crisis, in view of the presence in the East China

7. "Talks on Japan-China Maritime Communication Deadlock," The Yomiuri Shimbun, 6 October 2015, http://the-japan-news.com/news/article/0002471385 (accessed on 11 March 2016).

8. "China Rejects Japan-proposed Maritime Liaison Mechanism," China Military Online, 8 October 2015, http://english.chinamil.com.cn/news-channels/pla-daily-commentary/2015-10/08/content_6713206.htm (accessed on 11 March 2016).

9. Quoted in "Diaoyu Islands Bring China-Japan Talks to a Stall in Discussion to Prevent Unwanted Conflict in East China Sea," South China Morning Post, 8 October 2015, www.scmp.com/news/ china/diplomacy-defence/article/1865079/diaoyu-islands-bring-china-japan-talks-stall-discussion (accessed on 15 July 2016).

10. Author's interview, Beijing, April 2016 


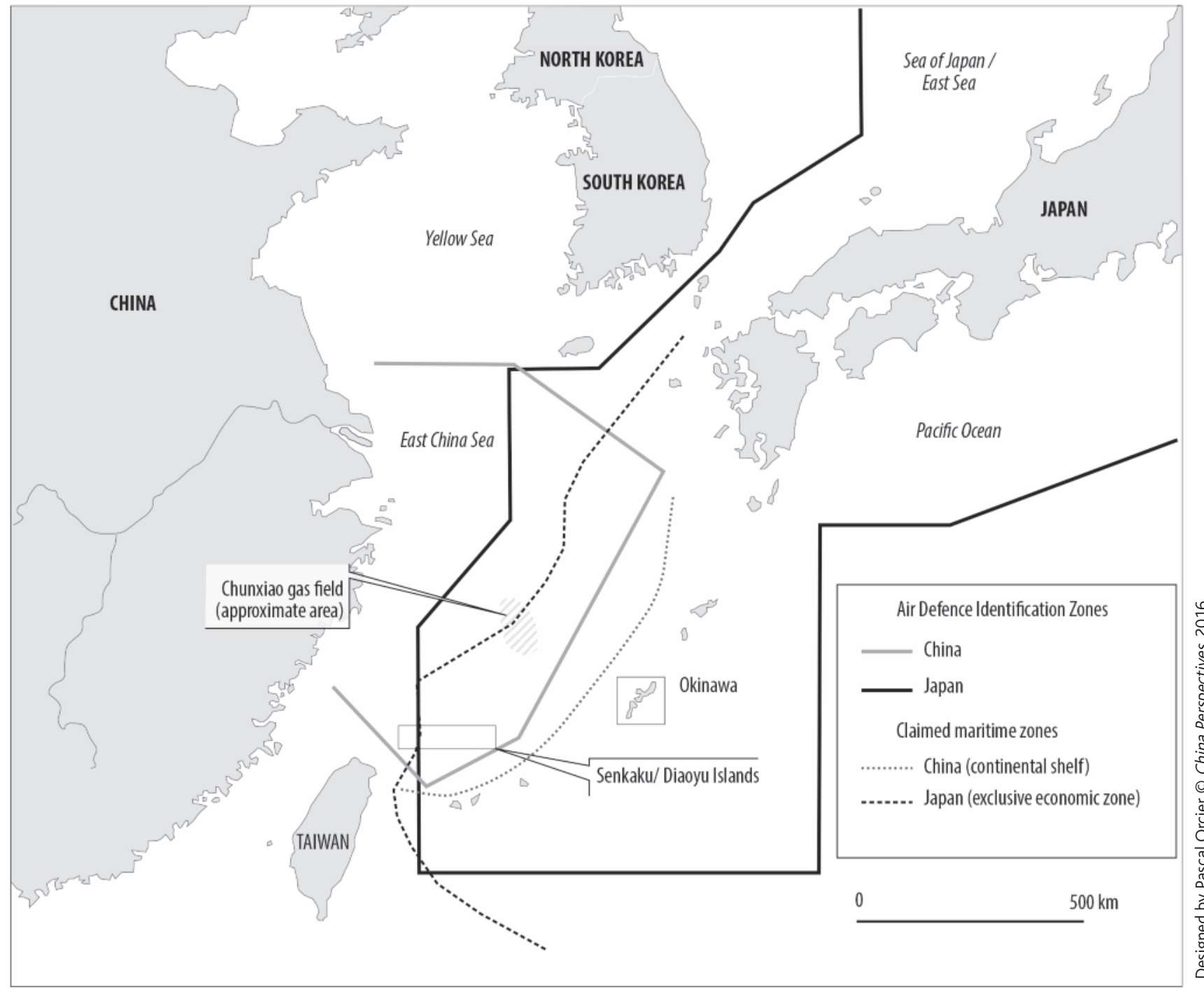

Source: Stockholm International Peace Research Institute, "Promoting Crisis Management in the East China Sea," February 2015, www.sipri.org/research/security/china/promoting-crisis-management-in-the-east-china-sea (accessed on 11 March 2016).

Sea of vessels of both sides. The negotiations in 2007 did not have the same sense of urgency that they later acquired at the end of 2012. It was conceived as a military confidence-building exercise in the context of two unresolved territorial disputes: the Senkaku/Diaoyu Islands sovereignty dispute and the EEZ/continental shelf delimitation dispute (see Map 1). According to a senior Japanese official speaking off the record, the goal on the Japanese side was also to establish a process by which regular interactions with the Chinese military would generate positive spill-over into the political relationship. ${ }^{(11)}$

The first round of talks regarding the establishment of a MACM (called Maritime Communication Mechanism [MCM] at the time) was held on 21 April 2008 in Beijing. In the lead were the Ministries of Defence of the two sides - the Foreign Affairs Office of the Ministry of Defence of the PRC and the International Policy Section of the Ministry of Defense of Japan. The two sides joined a working group whose composition underscores the unique specificity of the talks in the broader picture of JapanChina relations: they are the only ongoing negotiation led by the military on both sides.
Altogether, three rounds of talks took place before their interruption by China in September 2012 (see Table 2). At the June 2012 meeting, the joint Japan-China Working Group reached an understanding and agreed in principle to establish an MCM with three main pillars: 1) an annual meeting and regular expert meetings; 2) high-level hotlines between the defence authorities of the two countries; 3 ) direct communication between military vessels and aircraft (and an agreement on common radio frequencies). ${ }^{(12)}$ As a Japanese official involved in the negotiations noted, the understanding reached in June 2012 was good enough to put in practice and could have started operating until politics brought China-Japan tensions to a new peak. ${ }^{(13)}$ As of early 2015, the three elements of the structure agreed upon in 2012 were still the basis on which Chinese and Japanese negotiators were discussing a possible agreement.

11. Author's interview, Tokyo, February 2015.

12. Japan Ministry of Defense, Defense of Japan 2014 (Annual White Paper), Chapter 3, section 2, www.mod.go.jp/e/publ/w_paper/2014.html (accessed on 4 August 2016).

13. Author's interview, Tokyo, February 2015 
Table 2 - Chronology of China-Japan negotiations over a Maritime and Aerial Communication Mechanism (MACM)

\begin{tabular}{|c|l|}
\hline Date & \\
\hline 21 April 2008, Beijing & Inaugural meeting of the working group \\
\hline 26 July 2010, Tokyo & Discussion of the overall structure of the mechanism \\
\hline 28,29 June 2012, Beijing & Principled agreement on the structure of the mechanism, based on three pillars \\
\hline 12 January 2015, Tokyo & $\begin{array}{l}\text { Resumption of the talks; decision to expand the mechanism to also cover communication between aircraft; } \\
\text { decision to "implement the mechanism at an early date" }\end{array}$ \\
\hline June 2015 & Discussion on technical details and reiteration of importance of early implementation \\
\hline
\end{tabular}

Sources: James Przystup, John Bradford, and James Manicom, "Japan-China Maritime Confidence Building and Communications Mechanisms," Pacnet Newsletter, No. 67, 20 August 2013, https://www.csis.org/analysis/pacnet-67-japan-china-maritime-confidence-building-and-communications-mechanisms (accessed on 4 August 2016); Prime Minister of Japan and His Cabinet, "Press Conference of the Chief Cabinet Secretary," 13 January 2015, http://japan.kantei.go.jp/tyoukanpress/201501/13_a.html (accessed on 11 March 2016); email communication with senior Japanese foreign policy analyst, January 2016.

On 10 September 2012, the Government of Japan announced the purchase of three of the Senkaku/Diaoyu Islands. ${ }^{(14)}$ In retaliation, the Chinese government interrupted most communication channels. Even Track 2 security dialogues between academics and experts were cancelled. The purchase of the three islands, labelled "nationalisation" by the Chinese press, was described as "extremely dangerous" by the Xinhua News Agency and as "the most serious challenge to Chinese sovereignty after WW2" by the PLA Daily. ${ }^{(15)}$ The mainstream analysis in the Chinese strategic community was to understand the Japanese decision as a unilateral transformation of the status quo, which as such required retaliation to re-establish balance and build a new status quo. This narrative was for example elaborated by Zhang Junshe, a senior military officer with a PLA Navy think tank: "The status quo of the Diaoyu Islands, which had lasted for about four decades under the principle of shelving the dispute, was broken more than one year ago when the Japanese government launched a unilateral move to 'purchase' and 'nationalize' the islands." (16) During the period of interruption of the talks, tensions reached unprecedented levels, as described in greater detail in the second section of this article. Bilateral relations further deteriorated after Prime Minister Abe visited the Yasukuni Shrine in Tokyo on 26 December 2013. The Chinese Foreign Ministry spokesman reacted by saying that the visit "jeopardize(d) the political foundation of China-Japan relations and erect(ed) new barriers to the improvement and growth of bilateral relations," adding that the Japanese side had to "take all the consequences arising therefrom." (17) Thus the normalisation of bilateral diplomacy - including the resumption of crisis management negotiations - was tied by the Chinese side to a gesture by Japan on historical issues.

After a hiatus of almost three years, the negotiations finally resumed in January 2015 on the basis of a four-point consensus (commonly known in Chinese as sidian gongshi) reached in Beijing between Chinese State Councilor Yang Jiechi and Japanese National Security Advisor Yachi Shotaro in November 2014. The result of intense but very discreet diplomatic consultations, the consensus contained language on historical issues, a declaration of intention to develop the bilateral relationship on the basis of "common strategic interests," and a commitment to negotiating a crisis management mechanism. ${ }^{(18)}$ Crucially, the consensus paved the way for the first - and icy - summit meeting between Prime Minister Abe and Chinese President Xi Jinping since both took office, on the side-lines of the November 2014 APEC meeting in Beijing.
The Chinese Foreign Ministry reported a summit held at the request of the Japanese side that resulted in a decision to implement the "four-point agreement." (19) This endorsement at the highest political level in Beijing was the real turning point that made the resumption of talks a reality.

At their fourth round of talks in Tokyo on 12 January 2015, the two sides agreed that the mechanism should also cover the risk of air collisions, and not only focus on dangerous encounters at sea. They also agreed to implement the mechanism at an early date. This came after a series of risky close encounters between aircraft of the two sides in the aftermath of China establishing an Air Defence Identification Zone (ADIZ) in the East China Sea in November 2013. The name of the mechanism thus became "Maritime and Air Communication Mechanism." (20) A Japanese participant described the atmosphere as "friendly" and "highly constructive." (21) The fifth meeting, held in June 2015, was the occasion on which technical details were finalised regarding communication between aircraft. A lingering issue for the two sides in 2015 was whether there should be a public written agreement or if the content should remain confidential; according to interviews con-

14. These three islands are Minami-kojima, Kita-kojima, and Uotsuri-jima, which previously belonged to the Kurihara family. The objective of their purchase by the Japanese government was to nationalise them in order to prevent a similar initiative proposed in April 2012 by the Governor of Tokyo, the ultra-nationalist Shintaro Ishihara, who wanted to administratively incorporate these three islands into Tokyo's municipality, explaining that the Japanese authorities had not defended "Senkaku Islands" adequately against Chinese claims.

15. "China Voice: Japan Should Not Underestimate Severity of Diaoyu Island Issue," Xinhua, 11 September 2012, http://news.xinhuanet.com/english/china/2012-09/11/c_131843435.htm (accessed on 4 August 2016).

16. Zhang Junshe, "The US Should Take an Impartial Stance towards China's Newly-established ADIZ," China-US Focus, 3 December 2013, http://m.chinausfocus.com/article/2214.html (accessed on 11 March 2016).

17. Ministry of Foreign Affairs of the PRC, "Foreign Ministry Spokesperson Qin Gang's Regular Press Conference on December 26, 2013," www.fmprc.gov.cn/mfa_eng/xwfw_665399/s2510_665401/ 2511_665403/t1112269.shtml (accessed on 11 March 2016).

18. The Chinese and the Japanese sides issued different English translations of the consensus: "China, Japan Reach Four-point Agreement on Ties," Xinhua, 7 November 2014, http://news.xin huanet.com/english/china/2014-11/07/c_133772952.htm (accessed on 11 March 2016); MOFA, "Regarding Discussions Towards Improving China-Japan Relations," 7 November 2014, www.mofa.go.jp/a_o/c_m1/cn/page4e_000150.html (accessed on 11 March 2016).

19. Ministry of Foreign Affairs of the PRC, "Xi Jinping Meets Japanese Prime Minister Shinzo Abe," 10 November 2014, www.fmprc.gov.cn/mfa_eng/topics_665678/ytjhzzdrsrcldrfzshyjxghd/ t1209092.shtml (accessed on 11 March 2016).

20. Tetsuo Kotani, "Positive Signs for Crisis Management in the East China Sea," Asia Maritime Transparency Initiative, 4 February 2015, http://amti.csis.org/positive-signs-for-crisis-management-inthe-east-china-sea (accessed on 11 March 2016).

21. Author's interview, Tokyo, February 2015. 
ducted in Tokyo, the Japanese side insisted on a public version. (22) In the end, however, the key blocking factor was not related to that issue but to the geographical area covered by the agreement, which the Chinese side insisted should also apply to the 12 nautical miles territorial sea around the Senkaku/Diaoyu Islands; according to Chinese experts, the Japanese side insisted on explicitly excluding that region from the final agreement instead of not specifying the geographical area to which the agreement applied. (23)

As described in the second section, the risk of an incident rose tremendously after 2012, partly as a result of the involvement of Chinese law-enforcement agencies in the dispute, with a greater reactive role played by the Japanese Coast Guards. The Maritime and Air Communication Mechanism does not cover the activities of law-enforcement agencies. The two sides run a parallel consultation format, the "High-Level Consultation on Maritime Affairs," which brings together ministries and agencies involved in maritime security activities, including the Chinese State Oceanic Administration and the Japanese Coast Guard. (24) At the date of writing, these consultations were not aiming to finalise a specific agreement regulating the activities of the Coast Guards of the two countries but rather served as a confidence-building exercise at a very preliminary stage, since the Coast Guards have had even less bilateral interaction than the militaries. Several Japanese security experts advocated that once finalised, the military-tomilitary crisis management mechanism should be extended to the activities of law-enforcement agencies as well. (25)

\section{From reactive assertiveness to supporting a Maritime and Aerial Communication Mechanism}

On 7 September 2010, a Chinese fishing trawler collided with two Japanese Coast Guard ships in the vicinity of the Senkaku/Diaoyu Islands. The incident sparked a major outburst of tension in China-Japan relations. Japan detained the captain and the crew for ten days while the Chinese government accused Japan of unilateral violation of the status quo on the grounds that Japanese domestic law was used for the first time on a territory claimed by China. While the crew was subsequently released, the developments around the collision - political tensions, diplomatic exchanges of fire, anti-Japan demonstrations in China, and anti-Chinese sentiment rising in Japan - made clear that such incidents could generate considerable deterioration of bilateral relations and in a worst case scenario push the two nations to the brink of armed conflict. A precedent was set - it illustrated the importance of crisis management as an instrument of stability.

There is a certain asymmetry in the way China and Japan perceive the maritime and aerial communication mechanism. Concluding a crisis management agreement has been a priority of Prime Minister Abe's government. Japan's 2014 White Paper on defence policy noted that establishing the mechanism had become an "urgent matter" in light of recent near-collisions between the two militaries. The Japanese MOD described the mechanism as aiming to avoid "unexpected collision and prevent unforeseen consequences in waters and airspace from escalating into military clashes or political problems, as well as increasing mutual understanding and relationships of trust, and enhancing defence cooperation." (26) The necessity of reaching an agreement was much less overwhelming in Beijing, where the official discourse stressed the importance of a Japanese change of attitude prior to the resumption of negotiations. As a result, throughout the negotiation process, both sides maintained the perception that the crisis management mechanism was a Japanese initiative, and was primarily in the interest of Japan. Neither the Chinese Foreign Ministry nor the larger Chinese strategic community ever framed crisis management as a foreign policy priority. On the contrary, it was framed as a concession for the sake of strategic stability and under certain conditions only. In practice, China linked crisis management negotiations to two broader foreign policy goals: obtaining Japan's recognition of a sovereignty dispute over the Senkaku/Diaoyu Islands; and changing the Abe administration's approach to historical issues, especially visits to the Yasukuni Shrine, regarded by China as a major obstacle to the improvement of bilateral relations.

The Chinese strategic narrative was articulated around the idea that China had to reach a new status quo over the Senkaku/Diaoyu Islands after their "unilateral nationalisation" by Japan. To that end, the Chinese government went on the offensive in the East China Sea, choosing a policy of open confrontation. China's approach was aptly described in a report by the International Crisis Group as "reactive assertiveness." (27) The aim of the offensive was to achieve a situation of contested administration of the islands - a goal never officially acknowledged but quietly pursued by means of three key decisions. The new status quo sought by Chinese policymakers was one whereby patrols of military forces and law-enforcement agencies of the two countries would regularly meet around the islands and in disputed areas of the East China Sea. As a result, Japanese sovereignty claims would be challenged not only at the political and diplomatic levels, but also at the more basic level of daily administration of the islands. A direct consequence of that policy was a tremendous increase in the risk of incident between the two sides.

First, China decided to send regular patrols into the territorial waters and the contiguous zone around the Senkaku/Diaoyu Islands. Graph 1 shows the frequency of Chinese patrols in the territorial seas (12 nm) and the contiguous zone ( $24 \mathrm{~nm}$ ) around the Senkaku/Diaoyu Islands. Figures on territorial seas show an exceptional presence before 2012. The turning point occurred in September 2012 with 13 patrols in reaction to the "nationalisation" of three islands by the government of Japan, which shows that patrols are conceived in Beijing as a retaliatory move to reestablish a new status quo. Monthly peaks occurred regularly from September 2012 to October 2013 reflecting high tensions in the political relationship and raising the risk of unintended collision. In April and August 2013, 25 and 28 Chinese vessels were identified by Japan inside the $12 \mathrm{~nm}$ zone. Another turning point occurred in October 2013, with a "routinisation" of patrols at around 10 per month in the territorial seas of the islands. The stabilisation of the frequency of patrols after a peak gives credit to the thesis that China has achieved regular contest "on the ground" of Japan's administration of the islands.

A key determinant of China's approach to crisis management in the East China Sea is the rapid modernisation of China's law-enforcement capability.

22. Author's interview with Japanese official, Tokyo, February 2015.

23. Author's interviews with Chinese and Japanese experts, April 2016.

24. James Przystup, John Bradford, and James Manicom, "Japan-China Maritime Confidence Building And Communications Mechanisms," Pacnet Newsletter, No. 67, 20 August 2013, https://www.csis.org/analysis/pacnet-67-japan-china-maritime-confidence-building-and-communications-mechanisms (accessed on 4 August 2016).

25. Author's interviews, Beijing, Tokyo, Stockholm, 2013-2015.

26. Japan Ministry of Defense, Defense of Japan 2014 (Annual White Paper), Chapter 3, section 2, www.mod.go.jp/e/publ/w_paper/2014.html (accessed on 4 August 2016).

27. International Crisis Group, "Dangerous Waters: China-Japan Relations on the Rocks," Asia Report, No. 245, 8 April 2013, pp. 12-15. The report defines reactive assertiveness the following way: "Beijing uses an action by another party as justification to push back hard and change the facts on the ground in its favour." 


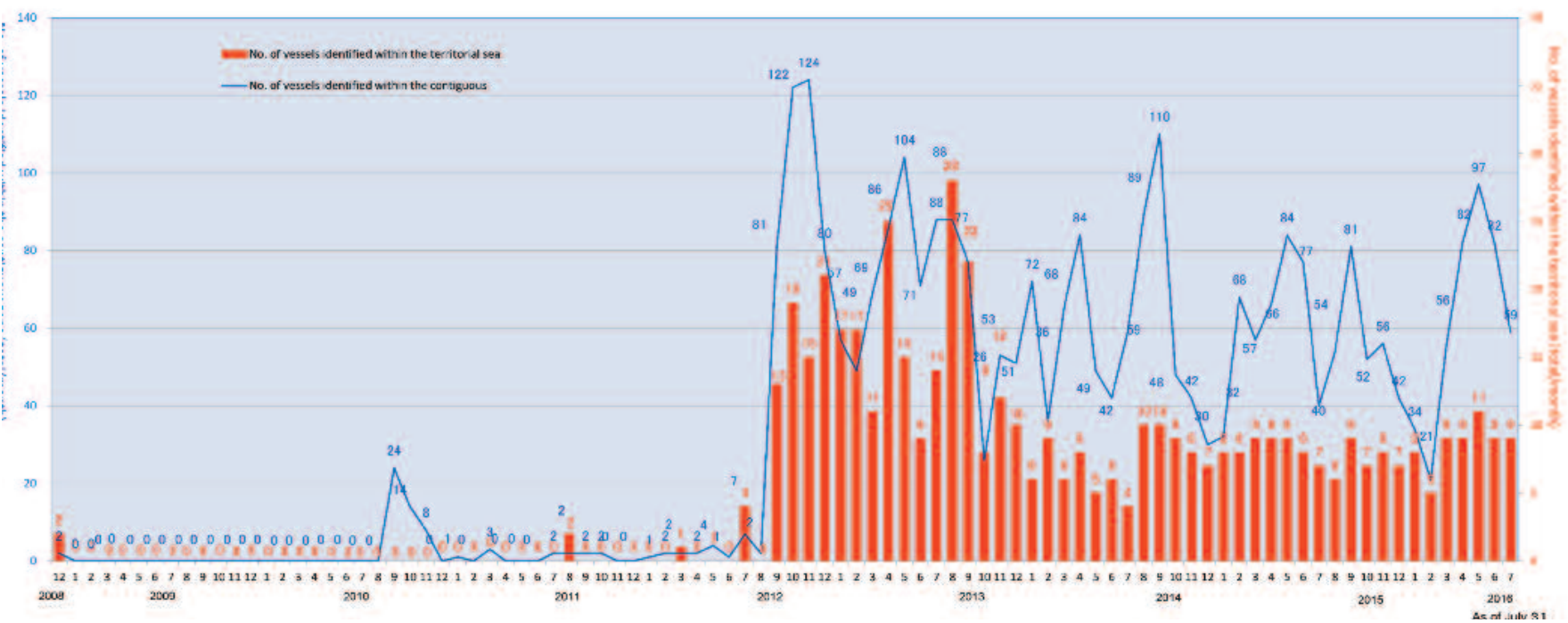

(C) Ministry of Foreign Affairs of Japan (MOFA)

Source: Courtesy of the Ministry of Foreign Affairs of Japan (MOFA), "The Numbers of Chinese Government and other Vessels that Entered Japan's Contiguous Zone or Intruded into Territorial Sea Surrounding the Senkaku Islands (As of July 31)," graph accessible at www.mofa.go.jp/files/000170838.pdf (accessed on 18 August 2016).

In this regard the reform of China's maritime law-enforcement agencies was a key turning point that enabled China to standardise and systematise its strategy of patrols. In March 2013, the National People's Congress voted to reform China's maritime law-enforcement agencies, merging four agencies into a newly-established China Coast Guard. (28) The first occurrence of a Chinese ship with the new Coast Guard logo was July 2013. According to senior Japanese officials, a typical Coast Guard patrol involved a fleet of three ships, mostly between 1,000 and 3,000 tons but increasingly larger ships of about 5,000 tons; the possibility in the future of having 10,000-ton Coast Guard ships is considered serious in Japan. ${ }^{(29)}$ The Coast Guard fleet is commissioning refitted frigates from the PLA Navy and has adopted the design of the jiangkai frigate 054-D, in service in the PLAN, for a new class of 4,000-ton Coast Guard ships. ${ }^{(30)}$ The empowerment of the China Coast Guard and the State Oceanic Administration has kept tensions at a lower level than if the PLA Navy had been in charge of regular patrols, and seeks to send the political message domestically and internationally that the issue is a domestic one.

Second, Chinese air presence over the disputed islands also increased tremendously after 2012. In November 2013, China announced the establishment of an East China Sea ADIZ, overlapping Japan's in the East China Sea and over the Senkaku/Diaoyu Islands (see Map 1). While this is common practice for many states across the world, China's ADIZ was clearly part of a strategy to challenge Japan's administration of the islands, and a retaliatory move against the public purchase. The establishment of the ADIZ was also intended to change the global coverage of developments in the East China Sea. Chinese defence analysts regularly complain that Japan has an edge in terms of public diplomacy because it releases data on Chinese intrusions in its sovereign territories (used in this article), shaping the thinking of analysts worldwide and framing the public debate internationally. After the ADIZ was established, the Chinese English press started releasing information on Japanese intrusions into China's ADIZ. (31) While it is clear that China lacks the capacity to fully enforce its ADIZ regulations and interdict all military flights by Japan or the US, the announcement paved the way for increasing the frequency of Chinese air patrols in the area, and also created an argument based on domestic law to support the legitimacy of these patrols. China had only flown one aircraft (of the State Oceanic Administration) into the airspace of the Islands, in December 2012, when tensions with Japan reached a peak, but flights within the East China Sea north of the islands have increased since an ADIZ was declared. A good indicator of the impact on bilateral ties is the number of scrambles by the Japanese Air Force (see Graph 2).

Third, the PLA Navy's presence also increased near the Senkaku/Diaoyu Islands. In November 2015, a Dongdiao-class PLA Navy intelligence-gathering ship was identified south of the contiguous zone of the islands. (32) In June 2016, a PLA Navy ship was spotted inside the 24 nautical miles zone for the first time, and the Chinese Ambassador was summoned by the Japanese government. ${ }^{(33)}$ This marked a symbolic escalation following several occurrences of Chinese Navy ships drawing closer to the islands, and possibly in connection with the stalled crisis management negotiations, since for the first time the source of the stalemate become a concrete security problem, with a PLAN ship in the area to be included or excluded from the final agreement. By and large, Chinese naval strategy around the islands has been to show the flag through law-enforcement agencies and refrain from sending navy ships. There are at least two reasons for that. One

28. National People's Congress of the PRC website, "China to Restructure Oceanic Administration, Enhance Maritime Law Enforcement," 10 March 2013, www.npc.gov.cn/englishnpc/news/Events/ 2013-03/10/content_1774480.htm (accessed on 11 March 2016).

29. Author's interview, Tokyo, February 2015.

30. Ridzwan Rahmat, "Chinese Coast Guard Bolsters Fleet with Type 054A Missile Frigate-type Ship," Jane's Navy International, 2 June 2016, www.janes.com/article/60904/chinese-coast-guard-bolsters-fleet-with-type-054a-missile-frigate-type-ship (accessed on 4 August 2016).

31. "China Criticizes Japanese Intrusion in the East China Sea," Xinhua, 29 May 2014, http://news.xinhuanet.com/english/china/2014-05/29/c_133371426.htm (accessed on 4 August 2016).

32. "Chinese Naval Eavesdropping Ship Spotted near Senkaku," Japan Times, 13 November 2015, www.japantimes.co.jp/news/2015/11/13/national/chinese-naval-eavesdropping-ship-spottednear-senkakus/\#.V6NuShLmSGc (accessed on 4 August 2016).

33. Jonathan Soble, "Japan Summons Chinese Envoy After Naval Ship Nears Disputed Islands," The New York Times, 9 June 2016, www.nytimes.com/2016/06/10/world/asia/japan-china-navyprotest.html?_r=0 (accessed on 4 August 2016). 
is that law-enforcement ships project the political signal that this is about a routine public security operation on Chinese territory. Second, the lawenforcement presence guarantees a lower level of conflictuality, even though some armaments are carried on board the vessels. Ultimately, lawenforcement vessels can be backed by PLA Navy ships if they are in the vicinity, as made clear by several recent examples in the South China Sea.

As a result of this increased presence of armed vessels and aircraft, the need for a crisis management agreement became more urgent, as a series of nearcollisions made clear (see Table 3). A turning point occurred after the summer of 2014. In September, the High-Level Consultation on Maritime Affairs convened in Qingdao. This was the second meeting following the inaugural one in May 2012. The representatives of the two sides reached a consensus "in principle to resume consultations for an early implementation of a maritime communication mechanism between the defence authorities of the two countries." (34) This was followed by the November 2014 four-point consensus and the AbeXi summit in Beijing. The timeline suggests that a decision was taken in China to resume negotiations over the communication mechanism before a consensus was formally reached regarding the broader state of the relationship.

Why did China move from a policy centred on confrontation and assertiveness to a resumption of military diplomacy? The question is worth asking as the $\mathbf{2 0 1 4}$ "four points principled agreement" only vaguely addresses the preconditions that China had set for resuming talks with Japanese defence authorities. It does not include a Japanese recognition of the existence of a sovereignty dispute but an acknowledgement that "different positions" exist "regarding the tensions which have emerged in recent years." It does not include a Japanese commitment that the Prime Minister will no longer visit the Yasukuni Shrine but mentions the "spirit of facing history squarely and looking forward to the future." (35) As unspecific as it might read, the language of the document successfully defused China's sensitivities; it was in fact presented by Chinese experts as setting a new course for China-Japan relations under Xi Jinping and Shinzo Abe. (36) The document reflects a political decision to "create a space for ambiguity." (37) The following section discusses the possible causes of that political decision.

\section{Chinese experts' view on crisis management with Japan}

Crisis management (weiji guankong) is a relatively new term in China's strategic community. Negotiating security with rivals has traditionally been perceived in China as either a sign of weakness or leverage to extract political concessions. In China's maritime periphery, including the East and South China Seas and the Taiwan issue, where crisis management and confidence-building have repeatedly been recommended by security experts and frequently discussed at the Track 1 and 2 levels, no binding agreement was concluded between China and its rivals. In the South China Sea, no progress has been made since the 2002 Declaration on the Conduct of Parties in the South China Sea between China and ASEAN, a non-binding declaration that was supposed to pave the way for the signature of a binding code of conduct. A military hotline was finally established between China and Taiwan in December 2015, at a very late stage of the second term of Ma Ying-jeou in Taiwan, in a context of good political relations (after the Ma-Xi summit in Singapore), and at the height of the campaign for presidential and legislative elections in Taiwan. ${ }^{(38)}$ During periods of exceptional tension between the two sides of the Taiwan Strait, confidence-building measures were systematically raised by the Taiwanese side

\section{Graph 2 - Number of scrambles against Chinese} aircraft by JASDF (2001-2015)

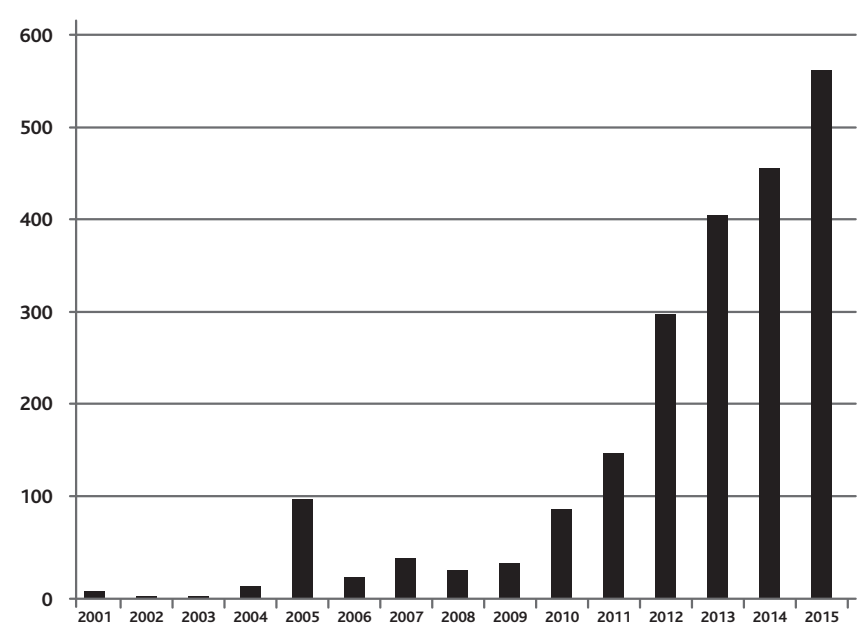

Source: Japan Ministry of Defense, "China's Activities Surrounding Japan's Airspace," www.mod.go.jp/e/d_act/ryouku (accessed on 12 August 2016).

and rejected by Beijing unless important concessions on sovereignty would be accepted by Taipei.

As a research field in security studies institutes, crisis management has attracted a degree of attention in China. Alastair lain Johnston has described how key research institutions within the Chinese military (National Defense University, China Foundation for International Strategic Studies) and the Ministry of State Security (China Institutes for Contemporary International Relations) have developed a body of theoretical literature on crisis management since the early 1990s, largely inspired by their study of American production on the same topic. ${ }^{(39)}$ Lessons learned from crises in US-China relations were particularly important in shaping the thinking in China regarding crisis management. Johnston notes that the structural contradiction between traditional military operational thinking and crisis management also applies to China, and tends to slow down the progress of advocates of crisis management. Overall, though, the number of in-depth Chinese publications on crisis management negotiations with Japan is extremely limited, and opinion pieces in Chinese language supporting the idea are even less numerous - although both exist.

Chinese analysts agree on the temporary nature of crisis management arrangements - by definition completely distinct from attempts at crisis resolution. A main dividing line relates to whether or not they see value in trying to stabilise a relationship by diminishing the risk of military incident or escalation in case an unintended collision occurs. Interviews conducted with maritime security experts in Beijing showed that many perceived the risk of incident as ultimately linked to "political will" - in other words, there is no incident if there is a political decision at the top to avoid dangerous behav-

34. Japanese MOFA, "Second Round Meeting of Japan-China High-Level Consultation on Maritime Affairs," 24 September 2014, www.mofa.go.jp/press/release/press1e_000016.html (accessed on 11 March 2016).

35. Quotes are from the English translation made public by Xinhua agency in China.

36. Author's interview with senior PLA analyst, Beijing, January 2016.

37. Ibid.

38. "Hotline between Chinese Mainland, Taiwan Launched," Xinhua, 30 December 2015, http://news. xinhuanet.com/english/2015-12/30/c_134964341.htm (accessed on 4 August 2016).

39. Alastair lain Johnston, "The Evolution of Interstate Security Crisis-Management Theory and Practice in China," art. cit. 


\begin{tabular}{|c|c|c|}
\hline Date & Event & Remarks \\
\hline 19 January 2013 & $\begin{array}{l}\text { A Chinese frigate locks fire control radar on Japanese naval helicopter } \\
\text { in the East China Sea }\end{array}$ & $\begin{array}{l}\text { PLA denies the facts, Japanese military } \\
\text { refuses to release evidence to protect } \\
\text { intelligence collection capacities }\end{array}$ \\
\hline 30 January 2013 & $\begin{array}{l}\text { A Chinese naval vessel locks fire control radar on a Japanese destroyer near disputed } \\
\text { islands in the East China Sea }\end{array}$ & $\begin{array}{l}\text { PLA denies the facts, Japanese military } \\
\text { refuses to release evidence to protect } \\
\text { intelligence collection capacities }\end{array}$ \\
\hline 24 May 2014 & Japan accuses China of dangerous flight 12 meters from Japanese aircraft & \\
\hline 11 June 2014 & $\begin{array}{l}\text { Two Japanese F- } 15 \text { fighters fly within } 30 \text { meters of a Chinese Tu- } 154 \text { in the overlapping } \\
\text { ADIZs while monitoring a Chinese military exercise }\end{array}$ & $\begin{array}{l}\text { Chinese MOD releases video and accuses } \\
\text { Japan of "seriously affecting flight safety" }\end{array}$ \\
\hline
\end{tabular}

Sources: "Japan Protests over China Ship's Radar Action," BBC News, 5 February 2013, www.bbc.com/news/world-asia-21337444 (accessed on 4 August 2016); "Japan May Release Data Proving Chinese Radar Incident," Reuters, 8 February 2013, www.reuters.com/article/us-japan-china-idUSBRE91801B20130209 (accessed on 4 August 2016); Sui-Lee Wee, "China Denounces Japan Protest over Military Jets' Close Brush," Reuters, 12 June 2014, www.reuters.com/article/us-china-japan-planes-idUSKBNOENOL720140612 (accessed on 4 August 2016)

iour. (40) Many Chinese analysts tend to associate crisis management with the notion of "strategic trust" (zhanlüe huxin), arguing that only the latter provides a solid foundation for a stable relationship. Hong Yuan (China Academy of Social Sciences) argues that crisis management negotiations reflect an overly micro approach and that only strategic trust at the level of the leadership can avoid military incidents; he combines this argument with a nationalistic discourse, presenting crisis management as a Western tool unfit for Asian states. ${ }^{(41)}$ Regular exchanges with Chinese think-tanks suggest that this school of thought dominates, although this is a qualitative assessment.

Some Chinese scholars have reflected on the lack of support for crisis management with Japan. Chu Xiaobo from Peking University argues that the wellknown Chinese word for crisis (weiji), composed of the characters "risk" and "opportunity" and widely commented in the West as revealing a specific Chinese approach to crises, is in fact limiting the thinking in China, because most thinkers tend to analyse crises exclusively in terms of seeking strategic opportunities. $\mathrm{He}$ also notes the absence of opinion leaders supporting the idea in public. ${ }^{(42)}$

At the same time, risk assessment in China has evolved as a result of close encounters involving the PLA, leading some Chinese analysts to acknowledge the risk of unexpected incident with Japan. For example, Chinese military analysts acknowledged the existence of four scenarios of incidents:

- A collision outside territorial waters involving naval forces, law-enforcement agencies, or fishing boats;

- A collision inside territorial waters;

- The landing of individuals on the islands;

- A military incident resulting from surveillance and reconnaissance activities in disputed areas. ${ }^{(43)}$

Shifting perceptions regarding the level of security risk is clearly a factor shaping China's approach to crisis management negotiations. However, a second main determinant is China's perception of the political benefits that can be secured through the negotiations. For example, Zhao Tong (Tsinghua University) argues that crisis management negotiations are the next logical step after the conclusion of the four-point consensus. He argues that for
China, crisis management has three goals: (1) avoiding incidents while the two sides protect their "de facto administration" (shiji kongzhiquan) of the islands; (2) avoiding escalation when incidents occur; (3) preventing limited incidents over sovereignty or historical issues from affecting the overall relationship. ${ }^{(44)}$ The first argument is the most interesting one, in the sense that it suggests a willingness to freeze a new status quo whereby Chinese ships would be accepted around the Senkaku/Diaoyu Islands by Japan, which would amount to a tacit acknowledgement by Japan of the notion of shared administration of the islands - anathema to the Abe administration.

Similarly, Yu Tiejun (Peking University) observes that crisis management negotiations are occurring as China has already successfully reached an intermediary goal in the East China, making the international community realise that there is a sovereignty dispute over the Senkaku/Diaoyu Islands and thus undermining the key feature of Japan's narrative. ${ }^{(45)}$ Throughout the seven years of negotiations, it also appeared clear - although it remains to be confirmed officially - that China was seeking very specific diplomatic outcomes. This appears in a paper published by Zhang Tuosheng, one the most prominent advocates of crisis management in China's strategic community: ${ }^{(46)}$

40. Author's interviews, Beijing, June 2014 and June 2014

41. Roundtable discussion at Charhar Institute on crisis management and China-Japan relations, reported in "Laizi Zhongwai zhuanjia de jianyi, ruhe bimian ZhongRi kaizhan" (Advice from Chinese and foreign experts: How to avoid the Sino-Japanese war), Huanqiuwang, 7 April 2015, http://opinion.huanqiu.com/opinion_world/2015-04/6116106.html (accessed on 11 March 2016).

42. Chu Xiaobo, "Dangqian ZhongRi guanxi yu waijiao weiji guanli" (Current Sino-Japanese relations and diplomatic crisis management), Dongbeiya xuekan, No. 4, July 2013, pp. $22-27$.

43. Oliver Bräuner, Joanne Chan, Fleur Huijskens, "Confrontation and Cooperation with Japan in the East China Sea: Chinese Perspectives," SIPRI Policy Brief, February 2015, http://books.sipri.org/ files/misc/SIPRIPB1502a.pdf (accessed on 4 August 2016).

44. Zhao Tong, "ZhongRi sidian gongshi mingque xia yi bu gongzuo zhongdian: weiji guankong" (China-Japan consensus on Four Points clears next priority: The crisis control), Zhongguowang, 10 November 2014, www.china.com.cn/opinion/think/2014-11/10/content_34012377.htm (accessed on 11 March 2016).

45. Yu Tiejun, "Dangqian chuli ZhongRi guanxi de zhongdian shi gaohao weiji guankong" (The focal point of the current deal with Sino-Japanese relations is to improve crisis management and control), 14 April 2014, www.21ccom.net/articles/qqsw/zlwj/article_20140414104366.html (accessed on 11 March 2016)

46. Zhang Tuosheng, "Building Trust between China and Japan, Lessons Learned from Bilateral Interactions in the East China Sea," SIPRI Policy Brief, February 2015, http://books.sipri.org/files/ misc/SIPRIPB1502c.pdf (accessed on 4 August 2016). 
- No personnel of either side should set foot on the islands or go within the 12-nautical-miles territorial-sea limit set by the United Nations Convention on the Law of the Sea (UNCLOS);

- Both sides should refrain from carrying out construction or other activities on the islands;

- No deployment of military assets of either side should take place near the islands or surrounding waters;

- Law enforcement vessels from both countries should keep an appropriate distance.

\section{China's choice: Political gain before military security risk}

Crisis management negotiations with Japan are failing on a predictable issue, sovereignty and different understandings of the nature of the status quo - precisely the element that needs to be set aside to achieve tangible outcomes. The Chinese insistence on applying the agreement in the $12 \mathrm{~nm}$ zone of the Senkaku/Diaoyu Islands was perceived by the Japanese side as a further attempt to degrade the de facto Japanese administration of the islands. This Chinese request followed a pattern of decisions taken since the Japanese public purchase of three islands in September 2012, all resulting in a de facto contestation of Japan's previously unchallenged administration of the islands - at least unchallenged at sea. In the end, it appears that China tried to achieve a more secure environment for their patrols in the disputed territorial waters around the Senkaku/Diaoyu Islands - waters in which they only very exceptionally operated before the negotiations started in 2008.

In addition to this core obstacle, over the course of the negotiations and especially after their resumption in 2015 , the Japanese side had two main security concerns regarding the usefulness of the mechanism, even though Japan remained committed to finalising the negotiations. The first was that China might use the mechanism and the negotiations "to neutralise a Japanese response to an incident and bind the Japanese military to a less than proportional response." (47) The second concern was related to the sustainability and efficiency of the mechanism. Would the Chinese military follow the rules of the agreement after having made diplomatic gains by signing it? Would the mechanism survive the next deterioration in bilateral relations over historical or other issues? These remain hypo- thetical questions as long as the mechanism is not in place, but they suggest that the level of distrust regarding Chinese military policy is very high in Tokyo.

To sum up China's approach to crisis management negotiations and their role in China's East China Sea policy, it appears that they have served two main goals:

- First, China's diplomacy on crisis management negotiations signals its overall assessment of the state of the relationship with Japan. In other words, it mirrors larger concerns instead of being used as an instrument to improve the overall relationship. During the summer of 2014, it appears that a decision was taken in Beijing to lower the level of tension with Japan, which led to a decision to resume the talks, a decision that was taken before the four-point consensus was even concluded.

- Second, in the particular case of the East China Sea, crisis management negotiations have been used to secure a new status quo after the purchase of the islands by the government of Japan, depicted by Beijing as a unilateral violation of the status quo ante. In other words, China tried to use the negotiations to consolidate the gains that had been achieved - from Beijing's perspective - through the unprecedented explosion in the number of patrols by law-enforcement agencies since the end of 2012.

This analysis suggests that China's approach to crisis management and confidence-building is overly determined by the search for political gain and is not sufficiently linked to a goal defined in terms of security; the risk of military incident is clearly not the main determinant of China's overall approach to negotiations with Japan and was never successfully isolated as an independent variable that should be addressed separately.

Mathieu Duchâtel is deputy director and senior fellow, Asia and China programme, at the European Council on Foreign Relations. European Council on Foreign Relations, 13 rue Paul Lelong, 75002 Paris, France (mathieu.duchatel@ecfr.eu).

Manuscript received on 14 March 2016. Accepted on 4 August 2016.

47. Marta McLellan Ross, "The Japan-China Maritime and Air Communication Mechanism, Operational and Strategic Considerations," Japan Institute of International Affairs, 30 June 2015, http://www2.jiia.or.jp/pdf/fellow_report/150630_Ms_Ross_ECS.pdf (accessed on 11 March 2016). 